\title{
Proximate composition of Turkish sesame seeds and characterization of their oils
}

\author{
By M. Kemal Ünal ${ }^{1}$ and Hasan Yalçın ${ }^{2}$ \\ ${ }^{1}$ Ege University Engineering Faculty, Department of Food Engineering, \\ 35100 Bornova Izmir-Turkey \\ ${ }^{2}$ Selçuk University, Engineering Faculty, Department of Food Engineering Konya -Turkey \\ Corresponding author: m.kemal.unal@ege.edu.tr
}

\section{RESUMEN}

Composición de semillas de sésamo de Turquía y caracterización de sus aceites.

Se ha evaluado la composición proximal de cuatro variedades de semillas de sésamo de Turquía así como el aceite obtenido mediante extracción en frío con hexano (composición en ácidos grasos, triglicéridos y esteroles). Las composiciones medias de las semillas fueron similares para todas las muestras siendo los valores medios $4,40 \%$, $4,41 \%, 21,00 \%, 54,26 \%$ para humedad, cenizas, proteínas y aceite, respectivamente. Los ácidos oleico y linoleico fueron los ácidos grasos mayoritarios mientras los ácidos palmítico y estearico fueron los principales ácidos saturados. Los triglicéridos mayoritarios, determinados mediante HPLC fueron LOL; LOO; PLO; LLL y OOO, suponiendo un $62,45 \%$ del porcentaje total de los triglicéridos. Los esteroles mayoritarios fueron $\beta$-sitosterol, campesterol, estigmasterol, y $\Delta-5$, avenasterol, identificándose también pequeñas cantidades de colesterol, clerosterol 5,24 estigmastedienol, $\Delta-7$ estigmastenol y avenasterol.

PALABRAS - CLAVE: Aceite de sesamo - Acidos grasos - Esteroles - Semillas de sésamo turcas - Triglicéridos.

\section{SUMMARY}

Proximate composition of Turkish sesame seeds and characterization of their oils.

A proximate composition of four varieties of Turkish sesame seeds (moisture, ash, protein, oil) was determined along with a characterization of their oils (fatty acids, triacylglycerols and desmethylsterols) The results of the proximate analysis showed the following contents: moisture, $4,40 \%$; ash, $4,41 \%$; protein $21,00 \%$; and oil, $54,26 \%$. Oleic and linoleic acids were the major unsaturated fatty acids while palmitic and stearic were the main saturated. The triacylglycerol composition of the sesame oil samples was determined by HPLC and LOL; LOO; PLO; LLL; OOO were the major triglycerides while triacylglycerols containing oleic and linoleic acyl residues comprize $62,45 \%$ of the total. The major desmethyl sterols found in sesame seed oils were $\beta$-sitosterol, campasterol, stigma-sterol, and $\Delta-5$, avenasterol. Small proportions of cholesterol, clerosterol 5,24 stigmastedienol, $\Delta-7$, stigmastenol and avenasterol were also identified.

KEY-WORDS: Fatty acids - Oil composition - Sterols Triacylglycerols - Turkish sesame seeds.

\section{INTRODUCTION}

Sesame seeds (Sesamum Indicum, L.) are one of the world's most important and oldest oilseed crops known to man (Garbia-Abau et al., 2000). Sesame, also known as sesamum, gingelly, benissed, sim-sim and till is an important annual oilseed crop. It has been cultivated for centuries, particularly in Asia and Africa, for it is high content in edible oil and protein. India, China, Sudan and Burma are the major producers of sesame seeds by contributing to approximately $60 \%$ of its total world production. Most of the sesame seeds are used for extraction and production of oil. The oil has a mild odor and pleasant taste and as such, is a natural salad oil requiring little or no winterization. It is a cooking oil in the form of shortening and margarine, as a soap fat in pharmaceuticals and as a synergist for insecticides, (Garbia-Abau et al., 2000).

A lot of sesame varieties and ecotypes which have been grown for hundreds of years are distributed in various ecological regions of Turkey (Baydar et al., 1999). Sesame cultivating in Turkey is most widespread in places influenced by a Mediterrenean climate with approximately 80.000ha. The use of improved breeding varieties in production is very limited because hundreds of local varieties and their ecotypes have adapted well to their own spesific conditions, (Baydar et al., 1999). Today, maintenance of local varieties plays a large role in preventing the loss of genetic variability in Turkish sesame populations. However, new commercial varieties may replace the local varieties in the near future (Baydar et al., 1999). The average anual production of sesame seeds in Turkey is 33.000 ton/year (Anon, 1999).

The objective of this study was to investigate the chemical composition of certain Turkish sesame seed varieties and their oils.

\section{MATERIALS AND METHODS}

\subsection{Materials}

Four different varieties of sesame seed (Sesamum İndicum, L.) samples, Gölmarmara, 
Muganlı, Özberk and Çamdibi, were used in this research. The Gölmarmara variety of samples was obtained from three different regions of Turkey; Antalya, Menemen, and Bornova. Muganlı; The Özberk and Çamdibi varieties were obtained from the Antalya and Menemen regions of Turkey respectively.

\subsection{Methods}

\subsubsection{Oil Extraction}

Sesame seed oil was extracted with hexane at $20{ }^{\circ} \mathrm{C}$ for 72 hours; then filtered. This process was repeated three times using fresh solvent each time in order to extract most of the oil from sesame seeds. Miscella was collected, mixed and evaporated at $50{ }^{\circ} \mathrm{C}$ under vacuum. Then the extracted oil was dried using anhydrous sodium sulphate.

\subsubsection{Analytical Determinations}

Protein and ash content were determined according to AOCS methods, 5-38 and 5-49 (AOCS, 1989). Crude protein was calculated using a nitrogen conversion factor of 6,25 . Moisture and oil content of sesame seeds were determined according to IUPAC 1.121-1.122. methods, respectively (IUPAC, 1979). The fatty acid methyl esters of lipids were prepared according to the AOAC method 991.39 (AOAC, 1980).

The analyses of fatty acid methyl esters were carried out with a Hewlett Packard Gas Chromatograph (model 5890) equipped with a hydrogen flame ionization detector and a capillary column; CP-Sil-88 Wcott fused silica $(50 \mathrm{~m} \times 0.25 \mathrm{~mm}$ id., of $0.20 \mathrm{~mm}$ film tickness). The temperatures of injector and detector were $270{ }^{\circ} \mathrm{C}$. The initial column temperature was $170^{\circ} \mathrm{C}$., and then raised to $205^{\circ} \mathrm{C}$ at a rate of $1^{\circ} \mathrm{C} / \mathrm{min}$. Split ratio was $1 / 50$. The carrier gas was hydrogen at a flow rate of $1 \mathrm{ml} / \mathrm{min}$. The identification and quantification of fatty acid methyl esters was accomplished by comparing retention times of the peaks with those of standards. The unsaponifiable matter was extracted after saponification of oil according to the standard method IUPAC 2.403 (IUPAC, 1979). The unsaponifiable matter was separated on TLC plates (20x20) precoated with silicagel $60(0.300 \mathrm{~mm})$. Elution was performed using benzen-aceton (95/5) as the mobile phase. The identification of the various compounds in the different unsaponifiable samples was achieved by comparison of their $R_{f}$ values with reference standards as described by Paganuzzi and Leoni (1979). Sterol fraction was silylilated according to Boven et al. (1997). Bis, trimethylsilyl-trifluoroacetamide (BSTFA) and trimethyl-chloro-silan were used for the sylilation procedure. The analysis of triacylglycerols (TAG) was performed according to the method proposed by the International Olive Oil Council (IOOC) (Anon, 1991). HPLC separations of TAG were conducted using a Lichrosphere 100 column $(250 \times 4.0 \mathrm{~mm}$,id). The elution solvent was at $1 \mathrm{~mL} / \mathrm{min}$ acetone/acetonitril $(70 / 30, v / v)$ at ambient temperature. The instrument used was a Hewlett Packard Model 1050 liquid chromatography equipped with a refractive index detector. Separated triacylglycerols as a function of equivalent carbon number ( $\mathrm{ECN}$ ) were identified using reference triglycerides and relative percentages were calculated automatically.

\section{RESULTS AND DISCUSSION}

The proximate chemical composition and fatty acid profile of Turkish sesame seeds and oils are presented in tables 1 and 2 .

The moisture contents found for the four varieties of sesame seeds from different regions of Turkey were between $4.16 \%$ and $4.62 \%$ with a marginal difference of $0.46 \%$. According to these results there are no significant differences due to variety in the moisture content of sesame seeds. Bahkali et al. (1993) reported that the moisture content of different cultivars from different countries was in the range of $3.65-5.60 \%$, which is in good agreement with these results. These values $(4.16 \%$ $4,62 \%)$ are also similar to the values reported (4.12\%-4.73\%) by Dashak and Fali (1998).

Ash content was found in the range from $3.88 \%$ (Gölmarmara-Menemen) to $5.30 \%$ (MuganlıMenemen). Özcan and Akgül (1995) determined values between from $3.67 \%$ to $5.39 \%$, for Turkish and foreign varieties (Mexican, Uganda and Venezuela) of sesame seeds. Protein content was found in the range of $18.00 \%$ to $23.18 \%$, with Gölmarmara (Menemen) being the variety with the highest protein content. These values are similar to the values reported from non-Nigerian bennised (Dashak and Fali, 1993). Table 1 also shows that sesame seeds have a high content of oil with

Table 1

Proximate chemical composition of Turkish sesame seeds

\begin{tabular}{|c|c|c|c|c|c|c|c|c|}
\hline \multirow[b]{2}{*}{ Analysis } & \multicolumn{7}{|c|}{ Variety of sesame seeds } & \multirow[b]{2}{*}{ Mean } \\
\hline & $\begin{array}{c}\text { Gölmarmara } \\
\text { (Antalya) }\end{array}$ & $\begin{array}{c}\text { Gölmarmara } \\
\text { (Menemen) }\end{array}$ & $\begin{array}{l}\text { Özberk } \\
\text { (Antalya) }\end{array}$ & $\begin{array}{c}\text { Özberk } \\
\text { (Menemen) }\end{array}$ & $\begin{array}{l}\text { Muganlı } \\
\text { (Antalya) }\end{array}$ & $\begin{array}{c}\text { Muganlı } \\
\text { (Menemen) }\end{array}$ & $\begin{array}{l}\text { Çamdibi } \\
\text { (Antalya) }\end{array}$ & \\
\hline Moisture \% & $4.47 \pm 0.10$ & $4.16 \pm 0.04$ & $4.56 \pm 0.04$ & $4.27 \pm 0.03$ & $4.44 \pm 0.05$ & $4.25 \pm 0.08$ & $4.62 \pm 0.03$ & $4.40 \pm 0.05$ \\
\hline Ash \% & $4.07 \pm 0.06$ & $3.88 \pm 0.06$ & $4.10 \pm 0.05$ & $4.37 \pm 0.06$ & $4.92 \pm 0.05$ & $5.30 \pm 0.03$ & $4.26 \pm 0.03$ & $4.41 \pm 0.05$ \\
\hline Protein \% & $21.13 \pm 0.05$ & $23.18 \pm 0.10$ & $21.17 \pm 0.09$ & $22.08 \pm 0.10$ & $18.00 \pm 0.10$ & $20.81 \pm 0.12$ & $20.68 \pm 0.06$ & $21.00 \pm 0.09$ \\
\hline Oil \% & $56.21 \pm 1.01$ & $56.50 \pm 1.15$ & $53.44 \pm 1.00$ & $54.06 \pm 0.95$ & $56.55 \pm 0.90$ & $50.57 \pm 1.00$ & $52.46 \pm 0.90$ & $54.26 \pm 0.99$ \\
\hline
\end{tabular}


Table 2

Faty acid profile of Turkish sesame seed oils

\begin{tabular}{lcccccccc}
\hline $\begin{array}{c}\text { Fatty acids } \\
\text { (area\%) }\end{array}$ & $\begin{array}{c}\text { Gölmarmara } \\
\text { (Antalya) }\end{array}$ & $\begin{array}{c}\text { Gölmarmara } \\
\text { (Menemen) }\end{array}$ & $\begin{array}{c}\text { Özberk } \\
\text { (Antalya) }\end{array}$ & $\begin{array}{c}\text { Özberk } \\
\text { (Menemen) }\end{array}$ & $\begin{array}{c}\text { Muganlı } \\
\text { (Antalya) }\end{array}$ & $\begin{array}{c}\text { Muganlı } \\
\text { (Menemen) }\end{array}$ & $\begin{array}{c}\text { Camdibi } \\
\text { (Antalya) }\end{array}$ & Mean \\
\hline C:14:0 & $0.02 \pm 0.003$ & $0.02 \pm 0.002$ & $0.02 \pm 0.002$ & $0.02 \pm 0.002$ & $0.02 \pm 0.003$ & $0.02 \pm 0.002$ & $0.03 \pm 0.002$ & $0.02 \pm 0.02$ \\
C:16:0 & $8.46 \pm 0.10$ & $9.44 \pm 0.08$ & $8.32 \pm 0.10$ & $8.95 \pm 0.11$ & $8.63 \pm 0.10$ & $9.08 \pm 0.12$ & $9.43 \pm 0.10$ & $8.90 \pm 0.10$ \\
C:16:1 & $0.12 \pm 0.005$ & $0.14 \pm 0.005$ & $0.11 \pm 0.005$ & $0.14 \pm 0.004$ & $0.13 \pm 0.004$ & $0.13 \pm 0.004$ & $0.12 \pm 0.005$ & $0.13 \pm 0.004$ \\
C:18:0 & $5.64 \pm 0.12$ & $5.76 \pm 0.10$ & $5.66 \pm 0.10$ & $5.20 \pm 0.10$ & $4.93 \pm 0.10$ & $5.26 \pm 0.14$ & $5.55 \pm 0.10$ & $5.43 \pm 0.07$ \\
C:18:1 & $41.06 \pm 0.50$ & $41.53 \pm 0.50$ & $42.42 \pm 0.35$ & $41.47 \pm 0.38$ & $40.62 \pm 0.30$ & $42.29 \pm 0.30$ & $41.66 \pm 0.32$ & $41.55 \pm 0.27$ \\
C:18:2 & $43.29 \pm 0.44$ & $41.67 \pm 0.40$ & $42.11 \pm 0.40$ & $42.87 \pm 0.55$ & $44.36 \pm 0.50$ & $41.88 \pm 0.53$ & $43.01 \pm 0.45$ & $42.74 \pm 0.47$ \\
C:18:3 & $0.59 \pm 0.01$ & $0.53 \pm 0.01$ & $0.57 \pm 0.01$ & $0.57 \pm 0.01$ & $0.58 \pm 0.01$ & $0.56 \pm 0.01$ & $0.60 \pm 0.01$ & $0.57 \pm 0.01$ \\
C:20:0 & $0.64 \pm 0.01$ & $0.69 \pm 0.02$ & $0.66 \pm 0.02$ & $0.62 \pm 0.02$ & $0.60 \pm 0.01$ & $0.64 \pm 0.01$ & $0.66 \pm 0.01$ & $0.64 \pm 0.01$ \\
C:20:1 & $0.03 \pm 0.005$ & $0.07 \pm 0.005$ & $0.01 \pm 0.004$ & $0.02 \pm 0.005$ & $0.03 \pm 0.005$ & $0.02 \pm 0.005$ & $0.03 \pm 0.005$ & $0.03 \pm 0.005$ \\
\hline
\end{tabular}

Muganlı (Menemen) being the variety with the lowest content $(50.57 \%)$. The economic value of sesame seeds is dependent on its oil content rather than its protein content. Bahkali et al.(1998) reported that the oil content of Saudi and Indian sesame seeds ranged from $43.2 \%$ to $54.0 \%$, a lower content than that found for Turkish sesame seeds. Baydar at al. (1999) also reported that oil content in the Turkish sesame seeds of the TSP 933749 line selected from the TSP 9337 population was found to be $63.25 \%$ which was significantly higher than the content of Indian, Lebanes and Saudi sesame varieties (Bahkali et al.1998).

Fatty acid compositions of the oils extracted are shown in Table 2. As can be observed, there are no significant differences between the varieties and oleic and linoleic acids are the main constituents accounting for more than $80.0 \%$ of the total fatty acids. Similar percentages were found for both fatty acids, the mean values being 42.74 and $41.55 \%$, respectively.

The distribution of triacylglycerols in sesame seed oils are given in table 3 . Eleven TAG species were determined and the main components were LOL $(20.87 \%)$ and LOO (19.12\%) followed by PLO (12.59\%),LLL (11.94\%), and OOO (10.52\%). The unsaturated TAG only containing oleic and linoleic acyl residues were $62.45 \%$ (mean value). TAG composition was in good agreement with data reported previosly and was also similar to those of corn and cottonseed oils (Nikolova-Damyanova et al., 2002).

Table 4 gives the results of the desmethyl sterol fraction of sesame seed oils. As shown in the table; the major desmethylsterols in sesame seed oils were $\beta$-sitosterol (62.68\%), campesterol (18.42\%), stigmasterol $(7.17 \%)$ and $\Delta-5$, avenasterol $(6.53$ $\%)$. Small proportions of cholesterol $(0.15 \%)$, clerosterol $(1.31 \%), \Delta-5,24$, stigmastadienol $(0.78 \%), \Delta$-7-stigmastadienol $(0.40 \%)$ and avenasterol were also identified. Oils from the four varieties and from different regions (Menemen, Antalya) were similar in their desmethylsterol composition and in agreement with those previously obtaned ( Kochhar 1983; Kamal-Eldin et al. 1992).

Table 3

Triacylglycerol composition of Turkish sesame seed oils

\begin{tabular}{|c|c|c|c|c|c|c|c|c|c|}
\hline \multicolumn{2}{|c|}{ Triacylglycerols } & \multicolumn{7}{|c|}{ Variety of sesame seeds } & \multirow{2}{*}{ Mean } \\
\hline & ECN & $\begin{array}{c}\text { Gölmarmara } \\
\text { (Antalya) }\end{array}$ & $\begin{array}{l}\text { Gölmarmara } \\
\text { (Menemen) }\end{array}$ & $\begin{array}{c}\text { Özberk } \\
\text { (Antalya) }\end{array}$ & $\begin{array}{c}\text { Özberk } \\
\text { (Menemen) }\end{array}$ & $\begin{array}{l}\text { Muganlı } \\
\text { (Antalya) }\end{array}$ & $\begin{array}{c}\text { Muganlı } \\
\text { (Menemen) }\end{array}$ & $\begin{array}{l}\text { Çamdibi } \\
\text { (Antalya) }\end{array}$ & \\
\hline LLL & 42 & $11.05 \pm 0.05$ & $10.60 \pm 0.05$ & $10.80 \pm 0.005$ & $11.39 \pm 0.04$ & $12.29 \pm 0.05$ & $10.72 \pm 0.05$ & $11.41 \pm 0.05$ & $11.94 \pm 0.05$ \\
\hline LOL & 44 & $21.35 \pm 0.30$ & $19.55 \pm 0.20$ & $20.63 \pm 0.25$ & $20.63 \pm 0.20$ & $21.59 \pm 0.20$ & $20.28 \pm 0.20$ & $21.68 \pm 0.20$ & $20.87 \pm 0.19$ \\
\hline PLL & 44 & $6.35 \pm 0.03$ & $6.24 \pm 0.03$ & $5.08 \pm 0.03$ & $6.36 \pm 0.02$ & $6.59 \pm 0.02$ & $6.14 \pm 0.03$ & $6.50 \pm 0.02$ & $6.18 \pm 0.03$ \\
\hline LOO & 44 & $19.27 \pm 0.10$ & $18.57 \pm 0.15$ & $19.83 \pm 0.18$ & $18.90 \pm 11$ & $18.86 \pm 0.10$ & $19.33 \pm 0.10$ & $19.06 \pm 0.10$ & $19.12 \pm 0.12$ \\
\hline PLO & 46 & $12.33 \pm 0.09$ & $12.99 \pm 0.09$ & $12.44 \pm 0.09$ & $12.49 \pm 0.08$ & $12.39 \pm 0.10$ & $12.95 \pm 0.09$ & $12.51 \pm 0.10$ & $12.59 \pm 0.09$ \\
\hline PLP & 46 & $1.07 \pm 0.02$ & $1.45 \pm 0.02$ & $1.20 \pm 0.02$ & $1.38 \pm 0.02$ & $1.35 \pm 0.02$ & $1.46 \pm 0.02$ & $1.15 \pm 0.02$ & $1.29 \pm 0.02$ \\
\hline 000 & 48 & $10.33 \pm 0.05$ & $10.61 \pm 0.05$ & $11.06 \pm 0.06$ & $10.64 \pm 0.05$ & $10.09 \pm 0.06$ & $10.83 \pm 0.06$ & $10.08 \pm 0.05$ & $10.52 \pm 0.05$ \\
\hline POO & 48 & $4.87 \pm 0.05$ & $6.01 \pm 0.05$ & $5.37 \pm 0.05$ & $5.51 \pm 0.06$ & $5.19 \pm 0.10$ & $5.87 \pm 0.06$ & $4.90 \pm 0.05$ & $5.39 \pm 0.06$ \\
\hline POP & 48 & $0.87 \pm 0.02$ & $1.23 \pm 0.02$ & $1.03 \pm 0.02$ & $1.08 \pm 0.01$ & $0.94 \pm 0.02$ & $1.11 \pm 0.02$ & $0.85 \pm 0.01$ & $1.02 \pm 0.02$ \\
\hline soo & 50 & $3.88 \pm 0.10$ & $4.12 \pm 0.12$ & $3.74 \pm 0.08$ & $3.71 \pm 0.10$ & $3.22 \pm 0.10$ & $3.91 \pm 0.10$ & $3.95 \pm 0.10$ & $3.79 \pm 0.10$ \\
\hline POS & 50 & $0.86 \pm 0.01$ & $1.21 \pm 0.01$ & $1.20 \pm 0.01$ & $1.04 \pm 0.01$ & $0.99 \pm 0.01$ & $1.18 \pm 0.01$ & $0.92 \pm 0.01$ & $1.06 \pm 0.01$ \\
\hline
\end{tabular}

P: palmitic S:Stearic O:Oleic L:Linoleic ECN:equivalent carbon number (total carbon number-2x number of total double bonds). 
Table 4

Desmethyl sterol composition of Turkish sesame seed oils

\begin{tabular}{|c|c|c|c|c|c|c|c|c|}
\hline \multirow{2}{*}{ Desmethyl sterol } & \multicolumn{7}{|c|}{ Variety of sesame seeds } & \multirow[b]{2}{*}{ Mean } \\
\hline & $\begin{array}{c}\text { Gölmarmara } \\
\text { (Antalya) }\end{array}$ & $\begin{array}{c}\text { Gölmarmara } \\
\text { (Menemen) }\end{array}$ & $\begin{array}{l}\text { Özberk } \\
\text { (Antalya) }\end{array}$ & $\begin{array}{c}\text { Özberk } \\
\text { (Menemen) }\end{array}$ & $\begin{array}{l}\text { Muganlı } \\
\text { (Antalya) }\end{array}$ & $\begin{array}{c}\text { Muganlı } \\
\text { (Menemen) }\end{array}$ & $\begin{array}{l}\text { Çamdibi } \\
\text { (Antalya) }\end{array}$ & \\
\hline Cholesterol & $0.23 \pm 0.005$ & $0.22 \pm 0.005$ & $0.18 \pm 0.004$ & $0.07 \pm 0.002$ & $0.14 \pm 0.001$ & $0.11 \pm 0.002$ & $08 \pm 0.001$ & $0.15 \pm 0.003$ \\
\hline Campesterol & $17.80 \pm 0.05$ & $17.86 \pm 0.05$ & $18.86 \pm 0.05$ & $18.79 \pm 0.06$ & $18.48 \pm 0.05$ & $18.53 \pm 0.05$ & $18.63 \pm 0.05$ & $18.42 \pm 0.05$ \\
\hline Stigmasterol & $7.41 \pm 0.02$ & $6.96 \pm 0.02$ & $7.42 \pm 0.03$ & $6.87 \pm 0.02$ & $6.90 \pm 0.02$ & $7.08 \pm 0.02$ & $7.55 \pm 0.02$ & $7.17 \pm 0.02$ \\
\hline Clerosterol & $1.79 \pm 0.01$ & $1.41 \pm 0.01$ & $1.20 \pm 0.01$ & $1.41 \pm 0.01$ & $1.24 \pm 0.01$ & $1.32 \pm 0.01$ & $0.82 \pm 0.01$ & $1.31 \pm 0.01$ \\
\hline$\beta$-sitosterol & $61.36 \pm 1.05$ & $62.94 \pm 0.95$ & $61.19 \pm 0.90$ & $62.55 \pm 0.90$ & $63.40 \pm 1.00$ & $64.02 \pm 1.02$ & $63.27 \pm 1.00$ & $62.68 \pm 0.97$ \\
\hline$\Delta-5$ avenasterol & $7.61 \pm 0.05$ & $6.58 \pm 0.05$ & $7.53 \pm 0.05$ & $6.82 \pm 0.06$ & $6.41 \pm 0.05$ & $5.39 \pm 0.05$ & $5.40 \pm 0.004$ & $6.53 \pm 0.05$ \\
\hline$\Delta 5,24$ stigmastadienol & $0.93 \pm 0.2$ & $0.74 \pm 0.01$ & $0.96 \pm 0.01$ & $0.75 \pm 0.02$ & $0.71 \pm 0.02$ & $0.58 \pm 0.02$ & $0.79 \pm 0.01$ & $0.78 \pm 0.02$ \\
\hline$\Delta$-7stigmastadienol & $0.42 \pm 0.01$ & $0.36 \pm 0.01$ & $0.48 \pm 0.01$ & $0.34 \pm 0.01$ & $0.31 \pm 0.01$ & $0.55 \pm 0.01$ & $0.34 \pm 0.01$ & $0.40 \pm 0.01$ \\
\hline$\Delta$-7avenasterol & $0.57 \pm 0.01$ & $0.75 \pm 0.01$ & $0.51 \pm 0.01$ & $0.58 \pm 0.01$ & $0.53 \pm 0.01$ & $0.68 \pm 0.01$ & $0.49 \pm 0.01$ & $0.59 \pm 0.01$ \\
\hline
\end{tabular}

\section{ACKNOWLEDGEMENTS}

This research was supported by the scientific research fund of Ege University.

\section{REFERENCES}

AOAC.1980. Official Methods of Analysis. Associations of Official Analitical Chemists, Washington, DC USA.

AOCS. 1989. Official Methods and recommended practice of the American Oil Chemist's Society 4th ed., Champaign, IL.

Anon .1991. International Olive Oil Council. (IOOC) T. 20.doc. no: 9

Anon. 1999. Agricultural structure and production. Başbakanlık Devlet İstatislik Enstitüsü, Ankara.

Bahkali AH, Hussain MA, Basahy AY.1998. Protein and oil composition of sesame seeds (Sesamum indicum, L.) grown in the Gizan area of Saudi Arabia. Int. J. Food Sci. Nutr. 49, 409-414.

Baydar H, Maquard R and Turgut I. 1999. Pure line selection for improved yield, oil content, and fatty acid composition of different sesamum indicum. Plant Breed. 118, 462-464.

Baydar H, Turgut I, Turgut K. 1999. Variation of certain characters and line selection for yield, oleic and linoleic acid in the Turkish sesame (sesamum indicum L.) populations. J. Agr. and Forest. 23., 431-441.
Boven MV, Daenes P, Maes K and Cokelaere M. 1997. Content and composition of free sterol and free fatty alcohols in jojoba oil. J Agric. Food Chem . 45. 1180-1184.

Dashak DA, Fali CN.1993. Chemical composition of four varieties of Nigerian bennised (sesamum indicum). Food Chem. 47. 253-255 .

Garbia-Abau AH, Shehata YAA, Shahidi F. 2000. Effect of processing on oxidative stability and lipid classes of sesame oil. Food Res. Int. 33, 331-340.

IUPAC.1979. Standart methods for the analysis of oils, fats and derivatives. (6th.edition) Oxford, UK. Pergamon Press .

Kamal-Eldin A, Ake-Appelqvist L,Yousif G and MinaIskander G. 1992. Seed lipids of sesamum indicum and related wild species in Sudan. J. Sci. Food Agric. 59, 327-334

Kochhar SP.1983. The effect of pocessing on vegetable oil sterols. Prog. Lipid Res. 22, 161-188.

Nikolova-Damyanova B, Velikova R, Kuleva L. 2002. Quantitative TLC for determination of the triacylglycerol composition of sesame seeds. J. Liq. Crom. Rel. Tech. 25,1623-1632.

Özcan M, Akgül A. 1995. Some compositional characteristics of sesame seed and oil. J. Agr. Forest. 19. 59-65.

Paganuzzi V, Leoni E. 1979. The composition of İranian olive oil. J.Am.Oil Chem Soc. 56, 925-930.

Recibido: $13 / 04 / 07$ Aceptado: 11/09/07 